\title{
KARAKTERISTIK CLEAT TERHADAP PERMEABILITAS DAN KANDUNGAN GAS PADA BATUBARA ANGGOTA M3 FORMASI MUARAENIM DI DAERAH MANGUNJAYA, PROVINSI SUMATRA SELATAN
}

\section{CLEAT CHARACTERIZATION ON PERMEABILITY AND GAS CONTENT IN M3 MEMBERS OF MUARAENIM FORMATION AT MANGUNJAYA AREA, SOUTH SUMATRA PROVINCE}

\author{
Muhammad Abdurachman Ibrahim ${ }^{1}$ dan Tito Harianto ${ }^{2}$ \\ ${ }^{1}$ Pusat Sumber Daya Mineral Batubara dan Panas Bumi \\ ${ }^{2}$ Universitas Padjajaran \\ abdurachman.ibrahim@esdm.go.id
}

\begin{abstract}
ABSTRAK
Cekungan Sumatra Selatan merupakan cekungan batubara dengan sumber daya batubara terbesar kedua di Indonesia. Hal ini membuka peluang untuk dapat memanfaatkannya, salah satunya yaitu melakukan eksplorasi gas metana batubara. Kandungan gas dan nilai permeabilitas sangat memengaruhi potensi gas metana batubara pada suatu wilayah. Permeabilitas batubara sangat dikontrol oleh sistem cleat yang berkembang pada lapisan batubara tersebut. Studi mengenai karakteristik cleat pada batubara sangat diperlukan untuk melihat kemungkinan jalur keluarnya gas metana dalam batubara. Penelitian ini dilakukan untuk mengetahui hubungan antara karakteristik batubara, sistem cleat yang berkembang, dan pendekatan nilai permeabilitasnya. Anggota M3 Formasi Muaraenim diambil sampel batubaranya untuk dilakukan analisis microcleat. Anggota M3 ini merupakan lapisan batubara yang tidak dalam, memiliki ketebalan yang cukup baik, dan merupakan target selain anggota M2 yang telah terbukti mempunyai potensi gas metana batubara. Analisis microcleat dilakukan untuk mengamati face cleat, butt cleat, aperture, dan spasi. Korelasi hasil perhitungan permeabilitas terhadap kandungan gas dan kedalaman lapisan batubara memberikan gambaran bahwa dengan semakin besar nilai permeabilitas, maka semakin besar kandungan gasnya.
\end{abstract}

Kata kunci: gas metana batubara, cleat, permeabilitas, kandungan gas

\section{ABSTRACT}

South Sumatra Basin is the second largest resource of coal basin in Indonesia. The abundance of coal in this basin has opened up opportunities to exploring coal bed methane. Gas content and permeability affect the potential of coal bed methane in an area. Coal permeability is highly controlled by the cleat system that develops in the coal seam. Studies on cleat characterization in coal are mandatory to see the possible escape routes of methane gas in coal. This research was conducted to determine the relationship between the characteristics of coal, cleat system, and permeability. Coals from M3 of Muaraenim Formation were sampled for microcleat analysis. Coals from M3 is not to deep, having a good coal thickness, and one of the coal bed methane seams target, M3 members can be another coal bed methane target, besides M2 members which have proved to be coal bed methane target. Microcleat analysis was performed to observe face cleat, butt cleat, aperture and spacing. The correlation between permeability to gas content and depth of coal, illustrates that the greater permeability, the greater gas content.

Keywords: coal bed methane, cleat, permeability, gas content 


\section{PENDAHULUAN}

Indonesia memiliki sumber daya batubara yang cukup signifikan, tetapi batubara yang terdapat pada kedalaman $>100 \mathrm{~m}$ masih banyak yang belum terungkap. Batubara bawah permukaan memiliki banyak potensi yang dapat dikembangkan, di antaranya tambang dalam (underground mining), mengubahnya menjadi gas melalui underground coal gasification dan diekstraksi kandungan gas metananya.

Cekungan Sumatra Selatan merupakan cekungan batubara dengan sumber daya batubara terbesar kedua di Indonesia. Sumber dayanya sebesar 51 miliar ton dan cadangannya sebesar 12 miliar ton. Sebagian besar batubara di cekungan ini termasuk batubara peringkat rendah hingga sedang $(<6.100 \mathrm{kal} / \mathrm{gr}$, adb) (PSDMBP, 2020). Keterdapatan batubara yang melimpah ini membuka peluang untuk dapat dimanfaatkan, salah satunya dengan memproduksi gas metana yang ada di batubara secara in-situ.

Eksplorasi dan eksploitasi gas metana batubara (GMB) belum dilakukan secara intensif, karena terbatasnya informasi dan studi mengenai gas tersebut. Salah satu aspek yang memengaruhi keekonomian suatu lapangan GMB adalah nilai permeabilitas. Permeabilitas batubara akan sangat dikontrol oleh sistem cleat yang berkembang pada lapisan batubara tersebut. Studi mengenai karakteristik cleat pada batubara sangat diperlukan untuk melihat kemungkinan jalur keluarnya gas metana dalam batubara. Cleat dapat disebabkan oleh beberapa faktor, yaitu aktivitas tektonik, struktur geologi, dan proses pembatubaraannya (Linggadipura, dkk., 2016; Yudha dan Purnama, 2019).

Penelitian ini dilakukan untuk mengetahui hubungan antara karakteristik batubara, sistem cleat yang berkembang, dan pendekatan nilai permeabilitasnya.

\section{GEOLOGI REGIONAL}

Secara regional, daerah penyelidikan termasuk dalam Cekungan Sumatra Selatan (Gambar 1). Cekungan ini terbentuk pada Pra-Tersier hingga Tersier Awal pada saat fasa ekstensi barat-timur (Darman dan Sidi, 2000).

Stratigrafi Tersier Cekungan Sumatra Selatan dibagi menjadi dua sekuen, yaitu fasa transgresif dan regresif. Kelompok Telisa, yaitu Formasi Gumai atau Telisa masuk dalam fasa transgresif. Kelompok Palembang, yaitu Formasi Airbenakat (Palembang Bawah), Formasi Muaraenim (Palembang Tengah), dan Formasi Kasai (Palembang Atas) masuk dalam fasa regresif (Patra Nusa Data, 2006).

Struktur geologi yang ada merupakan bagian dari fasa tektonik kompresi PlioPlistosen yang membentuk sesar-sesar dan antiklinorium pada batuan Tersier di Cekungan Sumatra Selatan. Antiklin dan sinklin saling berhubungan dengan arah sumbu lipatan barat laut-tenggara. Jurus perlapisan batuan secara regional berarah barat laut-tenggara dan timurlautbaratdaya, dengan kemiringan lapisan batuan mengikuti sayap lipatan. Sesar regional berarah barat laut-tenggara dan timur laut-barat daya (Patra Nusa Data, 2006).

Formasi Muaraenim sebagai formasi pembawa batubara mempunyai penyebaran cukup luas di daerah penelitian. Mengacu pada penyelidikan Shell (1978), dalam llyas dkk. (2000), formasi ini dibagi menjadi empat anggota. Urutan anggota dari tua ke muda, yaitu Anggota M1, M2, M3, dan M4. Setiap anggota memiliki lapisan batubara utama dengan ciri khas masing-masing lapisan (Tabel 1).

Anggota M1 mempunyai lapisan batubara utama, yaitu Lapisan Kladi dan Lapisan Merapi. Anggota M1 disusun oleh sedimen 
klastik halus yang terdiri dari batupasir, batulempung, batulanau, dan sisipan lapisan batubara tipis tidak menerus (Ilyas dkk., 2000).

Anggota M2 mempunyai lapisan batubara utama, yaitu Lapisan Petai, Lapisan Suban/Pengadang, dan Lapisan Mangus. Anggota M2 disusun oleh perselingan batulanau dengan batulempung dan sisipan batupasir dan batubara (llyas dkk., 2000).

Anggota M3 mempunyai lapisan batubara utama, yaitu Lapisan Burung dan Lapisan Benuang. Anggota M3 disusun oleh batupasir dan sedikit perselingan batulanau dengan batulempung serta beberapa lapisan batubara (llyas dkk., 2000).

Anggota M4 mempunyai lapisan batubara utama, yaitu Lapisan Kebon, Lapisan Babat, Lapisan Lematang, dan Lapisan Niru. Anggota M4 disusun oleh perselingan batupasir dan batulempung di bagian bawah, perselingan batulanau, dan batulempung di bagian atas serta beberapa lapisan batubara (llyas dkk., 2000).

Formasi Muaraenim di daerah penelitian mempunyai ketebalan antara 400-600 m yang diketahui dari hasil pengeboran minyak bumi dan mempunyai kemiringan relatif kecil, umumnya kurang dari $10^{\circ}$ (Ilyas dkk., 2000).

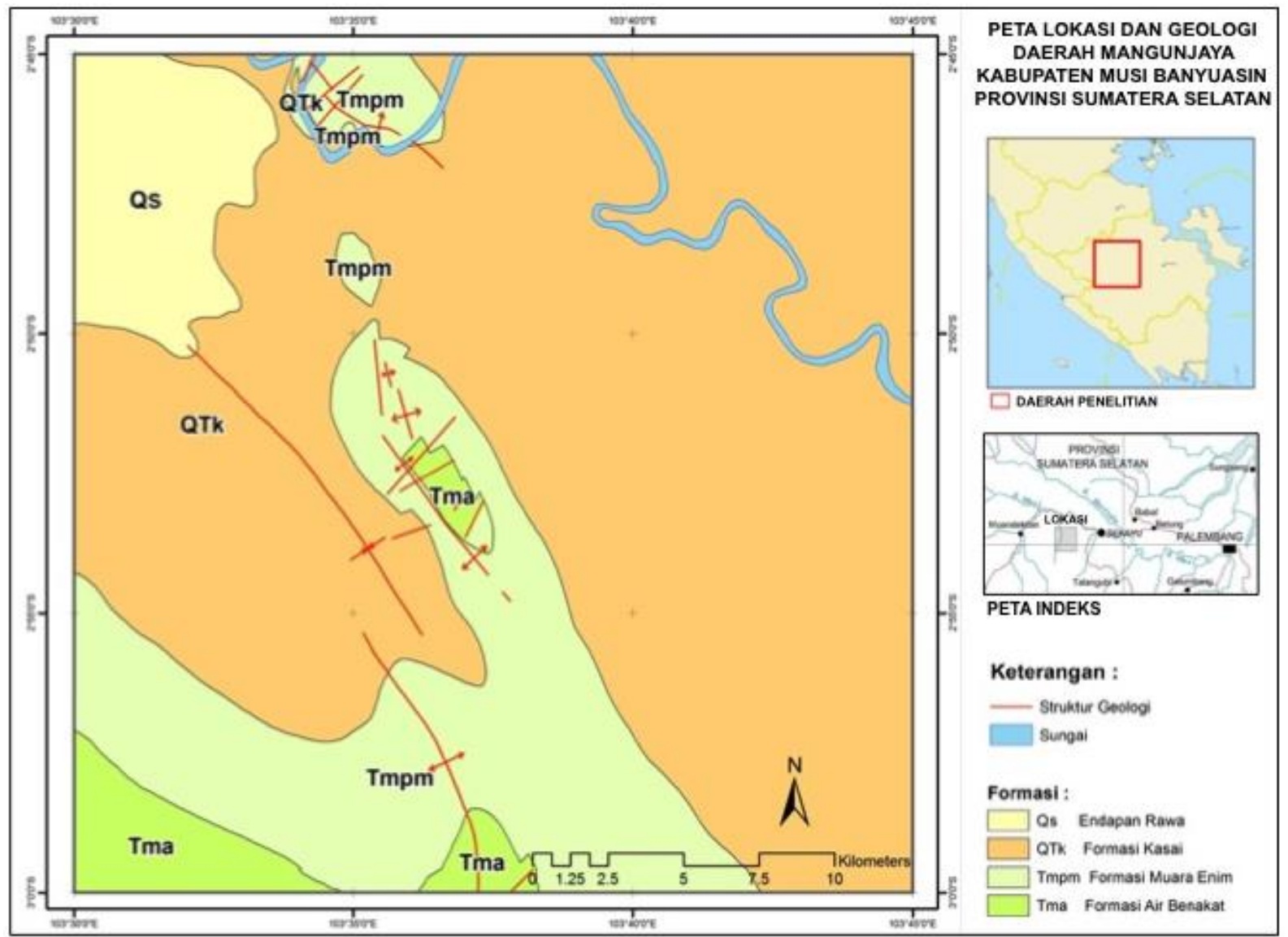

Gambar 1. Peta lokasi dan geologi daerah penelitian (Ibrahim dkk., 2017) 


\section{MAKALAH ILMIAH}

Tabel 1. Stratigrafi daerah Mangunjaya dan sekitarnya

(Shell, 1978, dalam llyas, dkk., 2000)

\begin{tabular}{|c|c|c|c|c|c|}
\hline \multirow{2}{*}{\multicolumn{2}{|c|}{ UMUR }} & \multirow{2}{*}{\multicolumn{2}{|c|}{$\begin{array}{l}\text { FORMASI } \\
\text { \& ANGGOTA }\end{array}$}} & \multicolumn{2}{|l|}{$\begin{array}{l}\text { CEKUNGAN SUMATERA SELATAN } \\
\text { (Shell Mijnbouw, 1978) }\end{array}$} \\
\hline & & & & PEMERIAN LITOLOGI & LAPISAN BB \\
\hline \multicolumn{2}{|c|}{ PLIOSEN } & \multicolumn{2}{|c|}{ KASAI } & Batulempung,biru-hijau, batupasir hijau glaukonitan, batu apung, lensa & \\
\hline \multirow[b]{3}{*}{ M } & & $\mathrm{M}$ & & ian lempung pasiran pasir halus-kasar. & Niru \\
\hline & \multirow{3}{*}{$\begin{array}{l}\text { A } \\
\text { T } \\
\text { A } \\
\text { S }\end{array}$} & $\mathrm{U}$ & M4 & $\begin{array}{l}\text { abu-abu - putih, sedikit glaukonit tebal } 120-200 \mathrm{~m} \text {, mengandung lapisan } \\
\text { batubara Niru, Lematang, Babat dan Kebon }\end{array}$ & $\begin{array}{l}\text { Lematang } \\
\text { Babat } \\
\text { Kebon }\end{array}$ \\
\hline & & R & M3 & $\begin{array}{l}\text { Perselingan batupasir dan batulanau, biru-hijau, batulempung abu-abu, } \\
\text { hijau dan coklat, horizon pasir } 3-6 \mathrm{~m} \text { terletak } 40 \mathrm{~m} \text { diatas lapisan batubara } \\
\text { Mangus dan terdapat kantong-kantong gas. Tebal } 100-280 \mathrm{~m} \text { mengandung } \\
\text { lapisan batubara Benuan dan Burung }\end{array}$ & $\begin{array}{l}\text { - Benuang } \\
\text { - Burung }\end{array}$ \\
\hline $\mathrm{S}$ & & $\begin{array}{l}\mathrm{E} \\
\mathrm{N}\end{array}$ & M2 & $\begin{array}{l}\text { Batulempung dan batulempung pasiran, coklat-abu-abu, batupasir halus - } \\
\text { sedang, abu-abu coklat, bagian bawah berwarna hijau abu-abu, tebal } 40- \\
120 \mathrm{~m} \text { mengandung lapisan batubara Mangus, Suban/Pengadang, dan Petai }\end{array}$ & $\begin{array}{l}\text { Mangus } \\
\text { Suban/Pengadang } \\
\text { Petai }\end{array}$ \\
\hline $\mathrm{E}$ & & M & M1 & $\begin{array}{l}\text { Batupasir, batulanau dan batulempung, abu-abu kecoklatan dan sedikit } \\
\text { glaukonitan, tebal } 100-250 \mathrm{~m} \text { mengandung lapisan batubara Merapi dan } \\
\text { Kladi }\end{array}$ & - Merapi \\
\hline $\mathrm{N}$ & $\begin{array}{l}\mathrm{T} \\
\mathrm{E} \\
\mathrm{N} \\
\mathrm{G} \\
\mathrm{A} \\
\mathrm{H}\end{array}$ & \multicolumn{2}{|c|}{ AIR BENAKAT } & $\begin{array}{l}\text { Batulempung dan serpih pasiran, abu-abu kecoklatan dan abu-abu kebiruan, } \\
\text { sebagian napalan, batupasir halus, abu-abu kehijauan, glaukonitan. }\end{array}$ & \\
\hline
\end{tabular}

\section{METODE}

Metode yang digunakan dalam penelitian ini yaitu analisis microcleat dengan mikroskop petrografi batuan terhadap sampel batubara dari lapisan I, J (Lapisan Benuang), dan $\mathrm{K}$ (Lapisan Burung), yaitu anggota M3 Formasi Muaraenim.

Analisis microcleat digunakan untuk melihat face cleat, butt cleat, mengukur spasi, dan mengukur aperture untuk menghitung pendekatan permeabilitas. Rumus perhitungan pendekatan permeabilitas berdasarkan sistem cleat menggunakan rumus dari Harpalani dan Chen (1995) dalam Suarez-Ruiz dan Crelling (2008) yang diadopsi untuk digunakan pada lapisan batubara. Rumus tersebut sebagai berikut:

$$
\begin{aligned}
\mathbf{k}=\mathbf{b}^{3} / 12 \mathbf{s} & \\
\text { dengan } \mathbf{k} & =\text { permeabilitas }(\mathrm{mD}) \\
\mathrm{b} & =\text { lebar rekahan/aperture }(\mathrm{mm}) \\
\mathrm{s} & =\text { spacing }(\mathrm{mm})
\end{aligned}
$$

Analisis laboratorium seperti peringkat batubara, proksimat, petrografi organik, kandungan gas, dan komposisi gas mengacu pada laporan batubara daerah Mangunjaya PSDMBP (2017).

Analisis data dilakukan dengan cara menghubungkan semua data yang ada menggunakan korelasi regresi, kemudian diambil kesimpulan melihat faktor-faktor yang ada.

\section{HASIL DAN PEMBAHASAN}

\section{Lapisan Batubara}

Data batubara pada penelitian ini didapatkan dari hasil pengeboran pada titik MJ02 yang telah dilakukan oleh PSDMBP pada tahun 2017 di daerah Mangunjaya. Bor MJ02 memiliki total kedalaman 485 m, menembus 11 lapisan batubara, dengan ketebalan bervariasi antara 0,36 s.d.14,35 $\mathrm{m}$. Lapisan batubara diberikan notasi $\mathrm{E}, \mathrm{F}$, G, I, J, K, L, M, N, O, dan P. Lapisan batubara disetarakan dengan Anggota M4, yaitu Lapisan Kebon (Lapisan E), Anggota 
M3 yaitu Lapisan Benuang (Lapisan J) dan Burung (Lapisan K), serta Anggota M2 yaitu Lapisan Mangus (Lapisan O) dan Suban (Lapisan P), sedangkan Lapisan F, G, I, L, M, N merupakan lapisan gantung atau bukan merupakan lapisan utama, seperti terlihat pada Tabel 2.

Batubara di daerah penelitian secara megaskopis mempunyai warna hitam kecoklatan, kusam (10\% cerah), gores coklat kehitaman, mengotori tangan, terdapat resin dan pirit, masih terlihat sisa tumbuhan, pengotor pada beberapa bagian berupa batubara lempungan dan batupasir kasar, pecahan subkonkoidal, cleat kadang terlihat, keras, rapuh, batas kontak dengan lapisan batuan lainnya gradasi hingga tegas (Ibrahim dkk., 2017).

Penelitian ini mengambil sampel batubara untuk dilakukan analisis microcleat pada lapisan I, J, dan K. Lapisan-lapisan batubara ini merupakan Anggota M3 Formasi Muaraenim. Anggota M3 merupakan lapisan batubara yang cukup tebal, dengan kedalaman lapisan batubara yang belum dalam, serta peringkat batubara sedang (5.100-6.100 kal/gr, adb). Anggota M3 ini dapat menjadi target batubara selain anggota M2 yang telah terbukti mempunyai potensi gas metana batubara.
Batubara Lapisan I pada lubang bor MJ02 berada pada kedalaman 79,30-81,18 meter dengan ketebalan 1,88 meter. Secara megaskopis berwarna hitam kecoklatan, masih terdapat sisa tumbuhan, dan berlapis. Kontak tajam planar dengan batulempung di bagian atasnya dan tajam tak beraturan dengan batupasir halus di bagian bawah (Ibrahim dkk., 2017).

Batubara Lapisan J/Benuang pada lubang bor MJ02 berada pada kedalaman 93,0099,25 meter dengan ketebalan 6,25 meter. Lapisan batubara ini berwarna hitam kecoklatan, masih terdapat sisa tumbuhan, dan berlapis. Kontak tajam planar dengan batulempung di bagian atasnya dan tajam tak beraturan dengan batupasir halus dibagian bawah (Ibrahim dkk., 2017).

Batubara Lapisan K/Burung pada lubang bor MJ02 berada pada kedalaman 117,65123,33 meter dengan ketebalan 5,68 meter. Pengotor pada lapisan batubara ini hanya resin dengan nodul batupasir, terdapat sisa tumbuhan, berlapis, kontak atas gradasi tak beraturan dengan batulanau, dan kontak bawah tegas planar dengan batupasir sangat halus hingga halus (Ibrahim dkk., 2017).

Tabel 2. Kedalaman lapisan batubara dari bor MJ02 (Ibrahim dkk., 2017)

Kedalaman Batubara MJ02

\begin{tabular}{cccc}
\hline Atap Lapisan $(\mathrm{m})$ & Dasar Lapisan $(\mathrm{m})$ & Tebal $(\mathrm{m})$ & Lapisan Batubara \\
\hline 9,20 & 23,55 & 14,35 & $\mathrm{E} /$ Kebon \\
\hline 27,07 & 29,33 & 2,26 & $\mathrm{~F}$ \\
\hline 44,50 & 45,45 & 0,95 & $\mathrm{G}$ \\
\hline 79,30 & 81,18 & 1,88 & $\mathrm{I}$ \\
\hline 93,00 & 99,25 & 6,25 & $\mathrm{~J} /$ Benuang \\
\hline 117,65 & 123,33 & 5,68 & $\mathrm{~K} /$ Burung \\
\hline 152,16 & 152,52 & 0,36 & $\mathrm{~L} 1$ \\
\hline 153,25 & 153,90 & 0,65 & $\mathrm{~L} 2$ \\
\hline 182,45 & 182,85 & 0,40 & $\mathrm{M}$ \\
\hline 228,16 & 228,96 & 0,80 & $\mathrm{~N}$ \\
\hline 260,46 & 271,10 & 10,64 & $\mathrm{O} /$ Mangus \\
\hline 281,30 & 282,80 & 1,50 & $\mathrm{P} /$ Suban \\
\hline
\end{tabular}


Hasil analisis proksimat dan nilai kalori batubara dari Lapisan I, J, dan K (Tabel 3), yaitu kandungan karbon tertambat (Fixed Carbon / FC) antara 37,25-42,25\% (adb), kandungan air (Moisture / M) antara 9,78$12,03 \%(\mathrm{adb})$, zat terbang (Volatile Matter / VM) antara 43,16-48,66\% (adb), kandungan abu (Ash) antara 2,85-4,43\% (adb), dan berat jenis antara 1,38-1,46. Nilai kalori batubara antara 5.561-5.952 $\mathrm{kal} / \mathrm{gram}(\mathrm{adb})$ atau 6.596-6.908 kal/gram (daf). Rata-rata nilai kalori Lapisan I, J, dan $\mathrm{K}$ yaitu $5.868 \mathrm{kal} / \mathrm{gram}$ (adb), 5.774 kal/gram (adb), dan $5.735 \mathrm{kal} / \mathrm{gram}$ (adb).

Hasil analisis petrografi organik (Tabel 3) memiliki nilai reflektansi vitrinit antara 0,24$0,32 \%$. Komposisi maseral didominasi oleh vitrinit antara 58,4-92,6\%, inertinit antara $1,8-33,6 \%$, dan liptinit antara $0,8-13,2 \%$. Material mineral yang ditemukan berupa lempung antara $0,8-7,6 \%$, oksida besi pada beberapa sampel sebesar $0,2 \%$, dan pirit antara 0,4-2,4\%. Rata-rata reflektansi vitrinit Lapisan I, J, dan $\mathrm{K}$ yaitu $0,27 \%$, $0,27 \%$, dan $0,28 \%$. Berdasarkan ASTM (1992), dilihat dari nilai reflektansi vitrinit, maka batubara Lapisan I, J, dan $\mathrm{K}$ termasuk dalam batubara peringkat lignit.

Menurut Sosrowidjojo (2013), reservoir lapisan batubara di Muaraenim yang mempunyai potensi GMB memiliki maseral vitrinit antara 58,9-83\%, reflektansi vitrinit antara $0,3-0,5 \%$, kandungan karbon tertambat (FC) antara 18,4-48,4\% (adb), kandungan air (M) antara 12,4-24,5\% (adb), zat terbang (VM) antara 29,1$53,97 \%$ (adb), kandungan abu (ash) antara $5,6-19,8 \%(\mathrm{adb})$, dan berat jenis antara 1,31,5. Berdasarkan nilai-nilai properti batubara untuk GMB tersebut, lapisan batubara I, J, dan $\mathrm{K}$ pada penelitian ini masih berada pada rentang tersebut, sehingga menjanjikan untuk menjadi reservoir GMB.

\section{Potensi GMB}

Analisis kandungan gas dalam batubara dilakukan dengan metode desorpsi menggunakan kanister, sementara analisis komposisi gas dilakukan menggunakan alat gas kromatografi yang diuji pada saat kegiatan lapangan. Hasil analisis komposisi gas menunjukkan prosentase gas metana dan gas lainnya seperti hidrogen, oksigen, nitrogen, dan karbondioksida.

Kandungan gas total dalam batubara ratarata dari Lapisan I sebesar 2,1025 scf/ton, Lapisan J sebesar 4,9462 scf/ton, dan Lapisan K sebesar 8,5177 scf/ton. Prosentase gas metana rata-rata Lapisan I sebesar 11,85\%, Lapisan J sebesar $23,22 \%$, dan Lapisan $\mathrm{K}$ sebesar $47,22 \%$. Kandungan gas metana rata-rata dari Lapisan I sebesar 0,2485 scf/ton, Lapisan J sebesar 1,1617 scf/ton, dan Lapisan $\mathrm{K}$ sebesar 3,9999 scf/ton. Kandungan gas dalam batubara meningkat dengan semakin dalamnya lapisan batubara. Prosentase gas metana juga meningkat seiring dengan bertambahnya kedalaman lapisan batubara (Tabel 4).

Berdasarkan hasil eksplorasi GMB oleh badan usaha di Cekungan Sumatra Selatan yang dikumpulkan Divisi Perencanaan Eksplorasi (2016), lapisan batubara anggota M3 Formasi Muaraenim memiliki ketebalan antara 2-12 m, dengan kandungan gas antara 12-76 scf/ton, pada kedalaman $>300 \mathrm{~m}$ (Tabel 5). Apabila kandungan gas dan komposisi gas metana semakin meningkat dengan diiringi bertambahnya kedalaman lapisan batubara, maka diinterpretasikan lapisan batubara I, J, dan K pada penelitian ini, dengan kedalaman $>300 \mathrm{~m}$, akan memiliki kandungan gas yang sesuai pada rentang tersebut, sehingga mempunyai potensi GMB. 

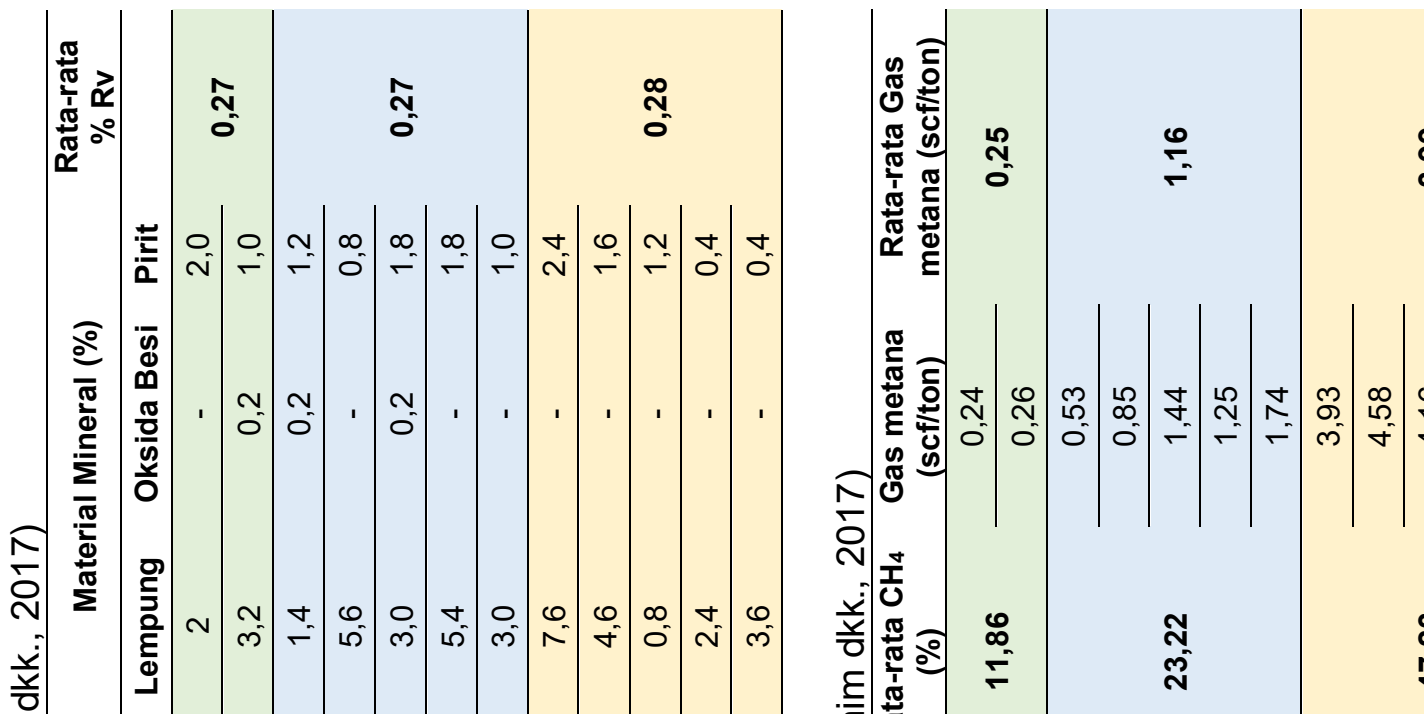

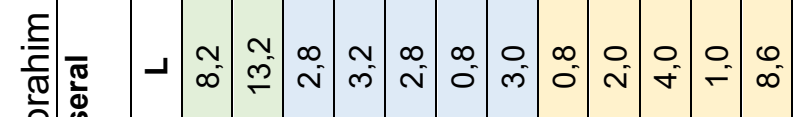
气 喜

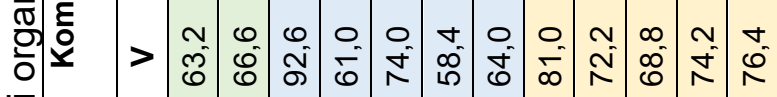

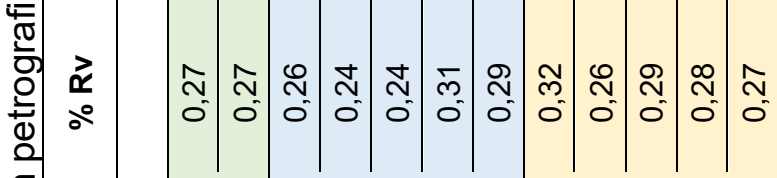
宁

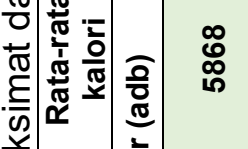

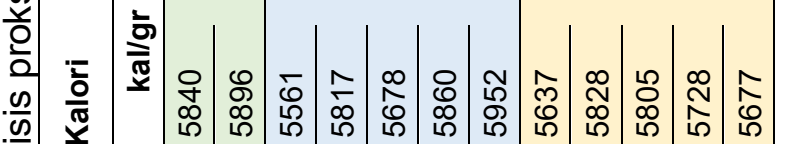
$\frac{\frac{9}{0}}{\frac{\pi}{\frac{D}{d}}}$

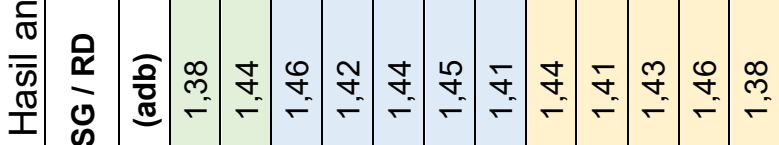

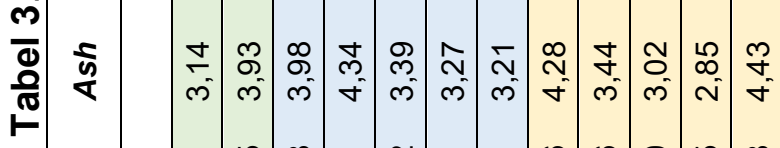

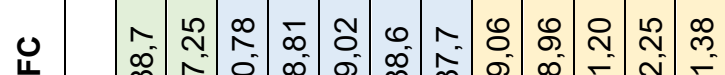
丩

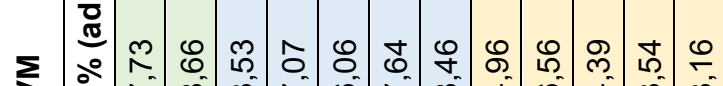

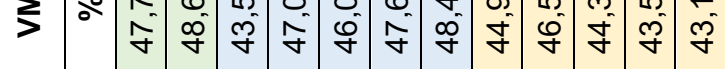

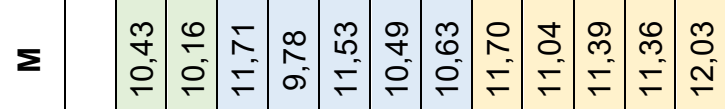

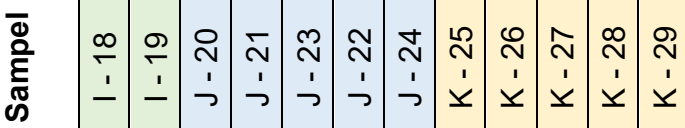

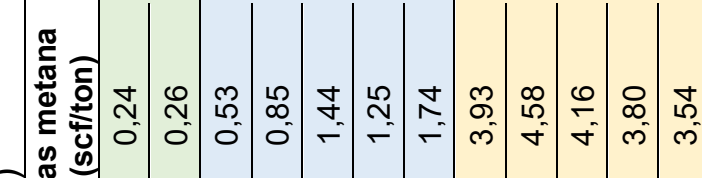
నิ

ํㅟ

经

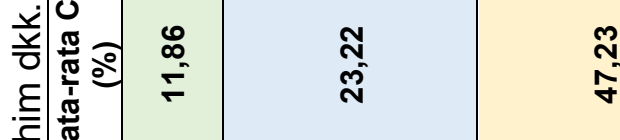
तิ

르

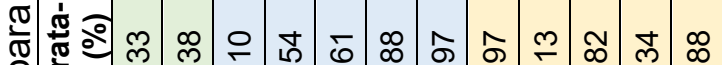

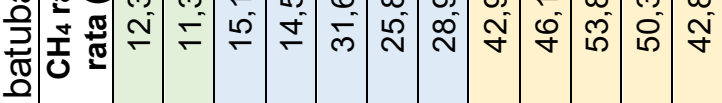

$\frac{\frac{E}{\sigma}}{\bar{\sigma}}$

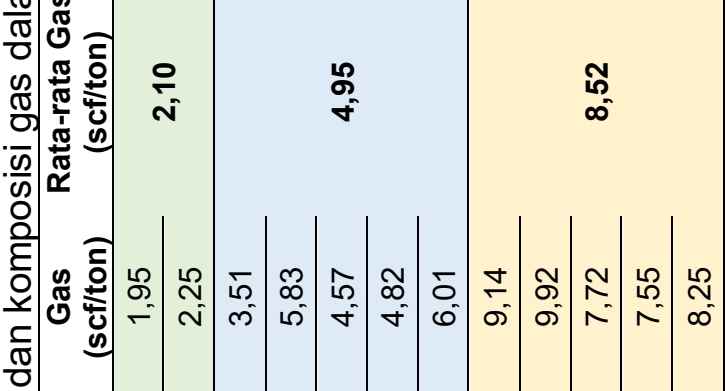
든 旁苛 गुण 辛 竎 jं ठै है ब⿳亠口冋.

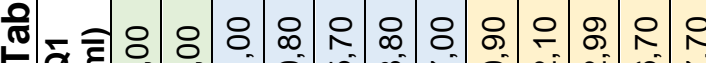

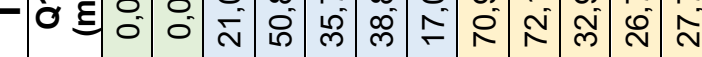
छ워 을 స

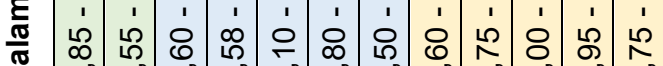
¿

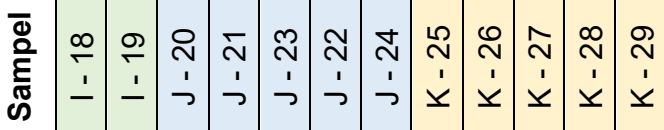




\section{MAKALAH ILMIAH}

Tabel 5. Hasil Eksplorasi GMB di Cekungan Sumatra Selatan

(Divisi Perencanaan Eksplorasi, 2016)

\begin{tabular}{|c|c|c|c|c|c|c|c|c|c|}
\hline \multirow[b]{2}{*}{ BASIN } & \multirow[b]{2}{*}{ AREA } & \multirow{2}{*}{$\begin{array}{l}\text { WORKING } \\
\text { AREA }\end{array}$} & \multirow{2}{*}{$\begin{array}{l}\text { DEPTH } \\
\text { TARGET }\end{array}$} & \multirow{2}{*}{\multicolumn{2}{|c|}{ FORMATION/ZONE }} & \multirow{2}{*}{\begin{tabular}{|c|} 
SEAMS \\
THICKNESS \\
$(\mathrm{m})$ \\
\end{tabular}} & \multirow{2}{*}{$\begin{array}{l}\text { GAS CONTENT } \\
\text { (Scf/ton) }\end{array}$} & \multirow{2}{*}{$\begin{array}{c}\text { PERMEABIUTY } \\
\text { (mD) }\end{array}$} & \multirow{2}{*}{$\begin{array}{c}\text { PRODUCTION TEST } \\
\text { (gas) }\end{array}$} \\
\hline & & & & & & & & & \\
\hline \multirow{20}{*}{ South Sumatera } & \multirow{4}{*}{ Muara Enim } & ME & \multirow{4}{*}{$450-650 m$} & \multirow{4}{*}{ Muara Enim } & M4 & $x$ & $15-46 \mathrm{Scf} /$ Ton & $48-90 \mathrm{mD}$ & \multirow{4}{*}{$11-120 \mathrm{Mscfd}$} \\
\hline & & MEI & & & $M 3$ & $2-6 m$ & $12-76 \mathrm{Sct} /$ Ton & $92 \mathrm{mD}$ & \\
\hline & & MEII & & & $M 2$ & $6-23 m$ & $55-199 \mathrm{Scf} / \mathrm{Ton}$ & $7-16 \mathrm{mD}$ & \\
\hline & & MEIII & & & M1 & $1-3 \mathrm{~m}$ & $103 \mathrm{Scf} / \mathrm{Ton}$ & $x$ & \\
\hline & \multirow{4}{*}{ Suban } & \multirow{2}{*}{ Suban 1 } & \multirow{4}{*}{$400-550 m$} & \multirow{4}{*}{ Muara Enim } & M4 & $5-18 \mathrm{~m}$ & $18-22 \mathrm{Scf} / \mathrm{Ton}$ & $38-52 \mathrm{mD}$ & \multirow{4}{*}{$x$} \\
\hline & & & & & $\mathrm{M} 3$ & $x$ & $60-74$ Scf/Ton & $x$ & \\
\hline & & \multirow{2}{*}{ Suban II } & & & $M 2$ & $6.7 \mathrm{~m}$ & $80-120 \mathrm{Sct} / \mathrm{Ton}$ & $x$ & \\
\hline & & & & & M1 & $x$ & $\mathrm{x}$ & $x$ & \\
\hline & \multirow{4}{*}{ Tanjung Enim } & \multirow{4}{*}{ Tanjung Enim } & \multirow{4}{*}{$350-500 m$} & \multirow{4}{*}{ Muara Enim } & $\mathrm{MA}$ & $x$ & $x$ & $x$ & \multirow{4}{*}{$0.03 \mathrm{Mscfd}$} \\
\hline & & & & & $\mathrm{M} 3$ & $\mathrm{x}$ & $x$ & $x$ & \\
\hline & & & & & $M 2$ & $4-8 m$ & $107-122$ Scf/Ton & $x$ & \\
\hline & & & & & M1 & $\mathrm{x}$ & $\mathrm{x}$ & $x$ & \\
\hline & \multirow{4}{*}{$\begin{array}{l}\text { Ogan } \\
\text { Komering }\end{array}$} & \multirow{2}{*}{\begin{tabular}{|c|} 
Ogan \\
Komering I \\
\end{tabular}} & \multirow{4}{*}{$400-550 m$} & \multirow{4}{*}{ Muara Enim } & M4 & $0.9 \mathrm{~m}$ & $35 \mathrm{Scf} /$ Ton & $x$ & \multirow{4}{*}{$10 \mathrm{Mscfd}$} \\
\hline & & & & & $\mathrm{M3}$ & $2-12 m$ & $22-65$ Scf/Ton & $x$ & \\
\hline & & \multirow{2}{*}{\begin{tabular}{|c|} 
Ogan \\
Komering II
\end{tabular}} & & & $\mathrm{M} 2$ & $2-14 m$ & $33-89 \mathrm{Scf} /$ Ton & $10-35 \mathrm{mD}$ & \\
\hline & & & & & M1 & $\mathrm{x}$ & $\mathrm{x}$ & $x$ & \\
\hline & & Air Benalicat & \multirow{4}{*}{$300-400 m$} & \multirow{4}{*}{ Muara Enim } & $\mathrm{M} 4$ & $3-9.9 \mathrm{~m}$ & $28-82 \mathrm{Scf} /$ Ton & $13-27 \mathrm{mD}$ & \\
\hline & Air Benakat & ati & & & $\mathrm{M} 3$ & $2.8 m$ & $\mathrm{x}$ & $x$ & $x$ \\
\hline & & & & & $\mathrm{M} 2$ & $2.5-10 \mathrm{~m}$ & 38 - 108 Scf/Ton & $2-2.5 \mathrm{mD}$ & $x$ \\
\hline & & Ailr be & & & M1 & & & & \\
\hline
\end{tabular}

\section{Analisis Microcleat}

Karakteristik cleat (rekahan batubara) dapat dilihat melalui pengamatan terhadap jenis cleat, jarak antar-cleat (spasi), lebar bukaan (aperture), pengisi, panjang, orientasi bidang cleat, dan derajat fragmentasi cleat. Terdapat dua cleat dalam batubara, yaitu face cleat yang merupakan cleat utama, biasanya tidak terpotong oleh bidang cleat lainnya, dan butt cleat yang merupakan bidang cleat lainnya, biasanya tegak lurus terhadap bidang face cleat dan terpotong oleh adanya face cleat. Analisis microcleat dilakukan di bawah mikroskop untuk melihat spasi cleat, aperture, pengisi, dan panjang cleat, terhadap delapan sampel batubara lapisan I, J, dan K.

Sampel I19 diperoleh dari lapisan batubara pada kedalaman 80,55-81,10 m. Hasil analisis microcleat pada sampel 119 memperlihatkan cleat yang banyak dan memiliki rekahan yang jelas, sehingga mudah untuk membedakan antara face cleat dan butt cleat. Batubara ini memiliki bukaan (aperture) yang sedang dan tidak terisi mineral. Selain itu terdapat juga bukaan yang sempit pada beberapa tempat, khususnya pada butt cleat. Jarak spasi antar-cleat lebar. Terdapat mineral pirit pada sampel yang ditemukan pada bagian luar bukaan. Pengukuran aperture pada sampel ini menghasilkan 45 pengukuran face cleat, 25 pengukuran butt cleat, dan 18 pengukuran spasi (Gambar 2).

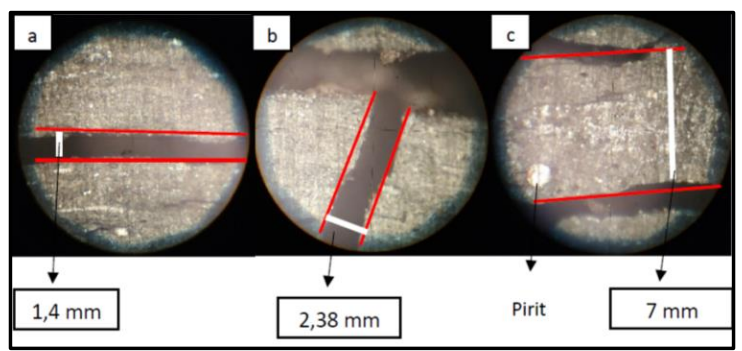

Gambar 2. Analisis microcleat sampel I19. a). face cleat b). butt cleat c). spasi

Sampel J21 diperoleh dari lapisan batubara pada kedalaman 94,13-94,58 m. Hasil analisis microcleat pada sampel J21 memperlihatkan rekahan yang banyak dan jelas, sehingga mudah untuk membedakan antara face cleat dan butt cleat. Memiliki variasi bukaan dari yang lebar hingga menyempit pada face cleat, serta di beberapa tempat terisi mineral. Pada butt cleat bukaan sedang hingga sempit. Jarak spasi antar-cleat lebar. Terdapat oksidasi pada sampel yang ditemukan pada bagian luar bukaan. Pengukuran aperture pada 
sampel ini menghasilkan 42 pengukuran face cleat, 24 pengukuran butt cleat, dan 17 pengukuran spasi.

Sampel J23 diperoleh dari lapisan batubara pada kedalaman 96,10-96,65 m. Hasil analisis microcleat pada sampel J23 memperlihatkan rekahan yang banyak tetapi kurang jelas, sehingga sulit untuk membedakan antara face cleat dan butt cleat. Memiliki bukaan yang lebar, akan tetapi kebanyakan terisi mineral pada face cleat. Pada butt cleat bukaan sedang hingga sempit. Jarak spasi antar-cleat lebar. Terdapat sklerotinit dari jamur menunjukkan lingkungan oksidasi dan lembab, ditemukan pada bagian luar bukaan, serta banyak ditemukan mineral pada aperture. Pengukuran aperture pada sampel ini menghasilkan 42 pengukuran face cleat, 20 pengukuran butt cleat, dan 16 pengukuran spasi.

Sampel J24 diperoleh dari lapisan batubara pada kedalaman 98,50-99,00 m. Hasil analisis microcleat pada sampel J24 memperlihatkan rekahan yang banyak, di beberapa tempat memiliki rekahan yang hancur, sehingga sulit membedakan antara face cleat dan butt cleat. Pada beberapa tempat memiliki bukaan yang lebar dan masih terdapat mineral pirit serta proses oksidasi. Selain itu terdapat bukaan yang sempit dan tidak menerus, sehingga kemenerusan cleat terputus. Jarak spasi antar-cleat lebar. Pengukuran aperture pada sampel ini menghasilkan 47 pengukuran face cleat, 16 pengukuran butt cleat, dan 15 pengukuran spasi.

Sampel K25 diperoleh dari lapisan batubara pada kedalaman 117,60-118,16 $\mathrm{m}$. Hasil analisis microcleat pada sampel K25 memperlihatkan rekahan yang banyak dan jelas, sehingga mudah untuk membedakan antara face cleat dan butt cleat. Face cleat memiliki bukaan yang lebar hingga sempit, pada beberapa tempat terisi mineral. Butt cleat memiliki bukaan yang sempit serta kemenerusan patahpatah, sehingga tidak menerus. Jarak spasi antar-cleat lebar. Pengukuran aperture pada sampel ini menghasilkan 38 perhitungan face cleat, 23 pengukuran butt cleat, dan 16 pengukuran spasi.

Sampel K26 diperoleh dari lapisan batubara pada kedalaman 118,75-119,30 $\mathrm{m}$. Hasil analisis microcleat pada sampel K26 memperlihatkan rekahan yang sedikit tetapi cukup jelas, sehingga mudah untuk membedakan antara face cleat dan butt cleat. Face cleat memiliki bukaan yang lebar hingga sempit. Butt cleat memiliki bukaan yang lebar, pada beberapa tempat terisi mineral, serta kemenerusan yang patah-patah. Jarak spasi antar-cleat lebar. Terdapat mineral pirit pada beberapa tempat di bagian luar aperture. Pengukuran aperture pada sampel ini menghasilkan 35 perhitungan face cleat, 18 pengukuran butt cleat, dan 14 pengukuran spasi.

Sampel K27 diperoleh dari lapisan batubara pada kedalaman 120,00-120,56 $\mathrm{m}$. Hasil analisis microcleat pada sampel K27 memperlihatkan rekahan yang sedikit tetapi cukup jelas, sehingga mudah untuk membedakan antara face cleat dan butt cleat. Face cleat memiliki bukaan yang lebar, di sekitar dan bagian dalam aperture terdapat beberapa mineral. Butt cleat memiliki bukaan yang sedang hingga sempit, beberapa tempat terisi mineral serta kemenerusan patah-patah. Jarak spasi antar-cleat lebar. Terdapat mineral pirit di beberapa tempat. Pengukuran aperture pada sampel ini menghasilkan 32 perhitungan face cleat, 15 pengukuran butt cleat, dan 12 pengukuran spasi.

Sampel K28 diperoleh dari lapisan batubara pada kedalaman 120,95-121,50 $\mathrm{m}$. Hasil analisis microcleat pada sampel K28 memperlihatkan rekahan yang sedikit tetapi cukup jelas, sehingga mudah untuk membedakan antara face cleat dan butt cleat. Face cleat memiliki bukaan yang cukup jelas. Butt cleat memiliki bukaan yang lebar hingga sempit, dengan kemenerusan yang patah-patah. Jarak spasi antar cleat lebar. Terdapat proses oksidasi pada beberapa tempat di luar bagian aperture. Pengukuran aperture 
pada sampel ini menghasilkan 40 perhitungan face cleat, 20 pengukuran butt cleat, dan 14 pengukuran spasi.

Cleat yang bukaannya terisi oleh mineral akan cenderung menghambat gas keluar dibandingkan dengan cleat yang bukaanya terbuka. Cleat yang terisi ini juga akan mengurangi permeabilitas dari batubara. Hal ini terlihat pada beberapa sampel yang memiliki bukaan terisi mineral, cleat cenderung tidak menerus, sehingga dapat mempengaruhi nilai permeabilitas (Linggadipura, dkk., 2016; Yudha dan Purnama, 2019).

Cleat juga dapat terbentuk oleh adanya aktivitas tektonik dan proses pembatubaraan. Cleat daerah Mangunjaya diinterpretasikan banyak dipengaruhi aktivitas tektonik. Hal ini terlihat oleh pengamatan jarak spasi cleat dan aperture cleat yang tidak mempunyai hubungan dengan proses pembebanan atau proses pembatubaraan. Cleat akibat proses endogenik atau bersamaan pembatubaraan akan cenderung tegak lurus bidang perlapisan, serta akibat tekanan dan temperatur cleat cederung mengecil. Cleat akibat eksogenik atau gaya tektonik akan cenderung memiliki dua pasang cleat yang saling membentuk sudut, serta tidak terlalu berpengaruh terhadap tekanan dan temperatur (Linggadipura, dkk., 2016; Yudha dan Purnama, 2019).

\section{Perhitungan Permeabilitas}

Perhitungan permeabilitas dengan rumus merupakan metode pendekatan terhadap nilai permeabilitas dari suatu sampel batubara yang dianalisis microcleat. Pendekatan permeabilitas ini digunakan untuk membantu dalam menganalisis suatu resenoir GMB. Hasil permeabilitas dari rumus mungkin saja akan berbeda dengan hasil nilai permeabilitas dengan metode tes langsung, akan tetapi nilai pendekatan permeabilitas sangat berguna untuk analisis lebih lanjut. Perhitungan permeabilitas menggunakan data dari face cleat sebagai rekahan utama dalam batubara.
Sampel I19 memiliki nilai aperture $1,0 \mathrm{~mm}$, spasi $3,6 \mathrm{~mm}$, dan pendekatan permeabilitas sebesar $0,02 \mathrm{mD}$. Sampel $\mathrm{J} 21$ memiliki nilai aperture $1,6 \mathrm{~mm}$, spasi $4,4 \mathrm{~mm}$, dan pendekatan permeabilitas sebesar $0,08 \mathrm{mD}$. Sampel J23 memiliki nilai aperture 2,0 $\mathrm{mm}$, spasi $6,6 \mathrm{~mm}$, dan pendekatan permeabilitas sebesar 0,10 $\mathrm{mD}$. Sampel J24 memiliki nilai aperture 1,2 $\mathrm{mm}$, spasi $3,8 \mathrm{~mm}$, dan pendekatan permeabilitas sebesar $0,04 \mathrm{mD}$. Sampel K25 memiliki nilai aperture 1,6 mm, spasi $3,7 \mathrm{~mm}$, dan pendekatan permeabilitas sebesar 0,09 mD. Sampel K26 memiliki nilai aperture $1,8 \mathrm{~mm}$, spasi $2,8 \mathrm{~mm}$, dan pendekatan permeabilitas sebesar 0,17 $\mathrm{mD}$. Sampel K27 memiliki nilai aperture 1,6 $\mathrm{mm}$, spasi $5,4 \mathrm{~mm}$, dan pendekatan permeabilitas sebesar 0,06 mD. Sampel K28 memiliki nilai aperture $2,4 \mathrm{~mm}$, spasi $3,6 \mathrm{~mm}$, dan pendekatan permeabilitas sebesar $0,32 \mathrm{mD}$.

Nilai pendekatan permeabilitas terkecil terdapat pada sampel I19 pada kedalaman $81,1 \mathrm{~m}$, sedangkan terbesar terdapat pada sampel K28 pada kedalaman 121,50 m. Rata-rata nilai pendekatan permeabilitas lapisan I, J, dan $\mathrm{K}$, yaitu $0,02 \mathrm{mD}, 0,07 \mathrm{mD}$, dan $0,16 \mathrm{mD}$. Nilai permeabilitas dalam lapisan batubara meningkat dengan semakin dalamnya lapisan batubara (Tabel 6).

Apabila lapisan batubara I, J, dan $\mathrm{K}$ berada pada kedalaman target GMB, yaitu $>300 \mathrm{~m}$, maka berdasarkan penelitian semakin dalam lapisan batubara dengan nilai permeabilitas semakin bertambah, anggota M3 Formasi Muaraenim dapat mempunyai potensi GMB. Menurut Sosrowidjojo (2013), potensi resenoir GMB di Formasi Muaraenim mempunyai nilai permeabilitas hingga $10 \mathrm{mD}$, sedangkan menurut hasil eksplorasi GMB oleh badan usaha di Cekungan Sumatra Selatan yang dikumpulkan Divisi Perencanaan Eksplorasi (2016), nilai permeabilitas anggota M3 Formasi Muaraenim dapat mencapai $92 \mathrm{mD}$. 


\section{MAKALAH ILMIAH}

Tabel 6. Hasil Perhitungan Permeabilitas

\begin{tabular}{|c|c|c|c|c|c|}
\hline Sampel & Kedalaman (m) & $\begin{array}{c}\text { Face Cleat } \\
\text { Aperture }(\mathrm{mm})\end{array}$ & $\begin{array}{l}\text { Face Cleat } \\
\text { Spasi }(\mathrm{mm})\end{array}$ & $\begin{array}{l}\text { Pendekatan } \\
\text { Permeabilitas } \\
\text { (mD) }\end{array}$ & $\begin{array}{c}\text { Rata-rata } \\
\text { Pendekatan } \\
\text { Permeabilitas (mD) }\end{array}$ \\
\hline $1-19$ & $80,55-81,10$ & 1,00 & 3,60 & 0,02 & 0,02 \\
\hline $\mathrm{J}-21$ & $94,58-94,13$ & 1,60 & 4,40 & 0,08 & \multirow{3}{*}{0,07} \\
\hline$J-23$ & $96,10-96,65$ & 2,00 & 6,60 & 0,10 & \\
\hline$J-24$ & $98,50-99,00$ & 1,20 & 3,80 & 0,04 & \\
\hline$K-25$ & $117,60-118,16$ & 1,60 & 3,70 & 0,09 & \multirow{4}{*}{0,16} \\
\hline $\mathrm{K}-26$ & $118,75-119,30$ & 1,80 & 2,80 & 0,17 & \\
\hline$K-27$ & $120,00-120,56$ & 1,60 & 5,40 & 0,06 & \\
\hline $\mathrm{K}-28$ & $120,95-121,50$ & 2,40 & 3,60 & 0,32 & \\
\hline
\end{tabular}

\section{Korelasi Regresi}

Hasil perhitungan permeabilitas dimasukkan dalam grafik untuk dihubungkan dengan berbagai parameter lainnya. Titik-titik korelasi dalam grafik juga dihubungkan dengan garis regresi linier untuk mendapatkan persamaan dan koefisien regresi. Nilai yang di plot hanya tiga mewakili nilai rata-rata berbagai parameter dari lapisan batubara I, J, dan K.

Keterkaitan antara pendekatan permeabilitas terhadap face cleat aperture berbanding lurus, sehingga semakin besar atau lebar aperture face cleat maka nilai permeabilitasnya juga semakin besar (Gambar 3).

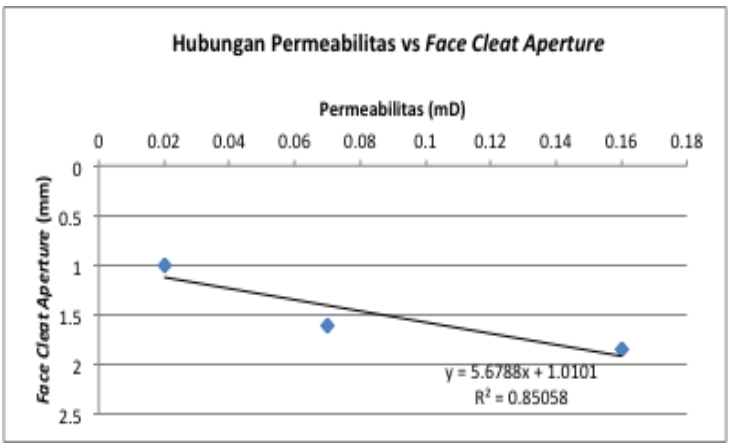

Gambar 3. Grafik permeabilitas terhadap face cleat aperture

Keterkaitan antara pendekatan permeabilitas terhadap face cleat spasi tidak saling berhubungan. Dapat diinterpretasikan bahwa pada penelitian ini nilai permeabilitas tidak berpengaruh langsung terhadap spasi face cleat (Gambar 4).

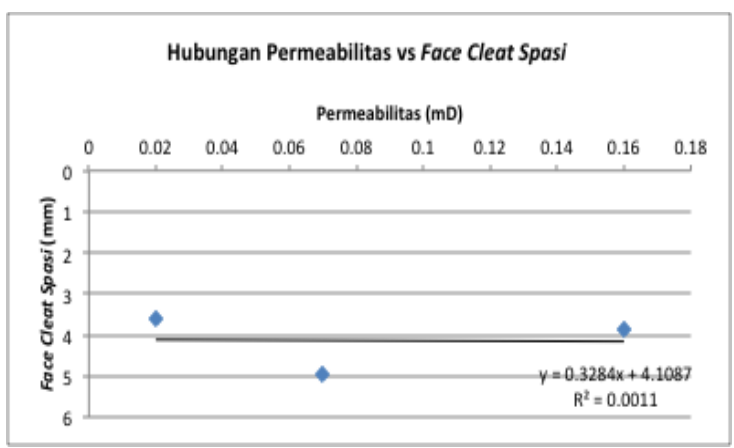

Gambar 4. Grafik permeabilitas terhadap face cleat spasi

Keterkaitan antara pendekatan permeabilitas terhadap kedalaman lapisan batubara berbanding lurus, sehingga semakin dalam lapisan batubara maka semakin besar nilai permeabilitasnya (Gambar 5).

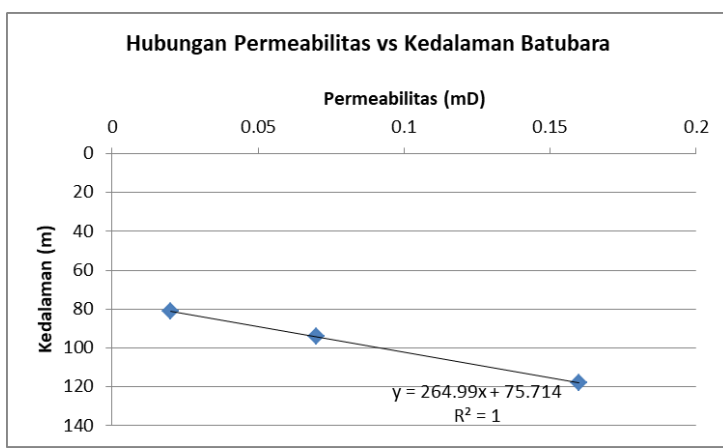

Gambar 5. Grafik permeabilitas terhadap kedalaman lapisan batubara

Keterkaitan antara pendekatan permeabilitas terhadap nilai kalori batubara berbanding terbalik (Gambar 6), sedangkan keterkaitan antara pendekatan permeabilitas terhadap reflektansi vitrinit 


\section{MAKALAH ILMIAH}

berbanding lurus (Gambar 7). Nilai kalori batubara meningkat dengan nilai permeabilitas yang semakin mengecil, sedangkan reflektansi vitrinit semakin meningkat diikuti nilai permeabilitas yang semakin besar.

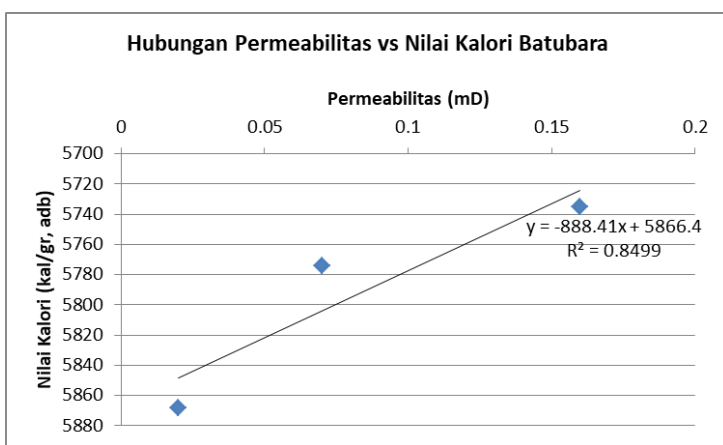

Gambar 6. Grafik permeabilitas terhadap nilai kalori batubara

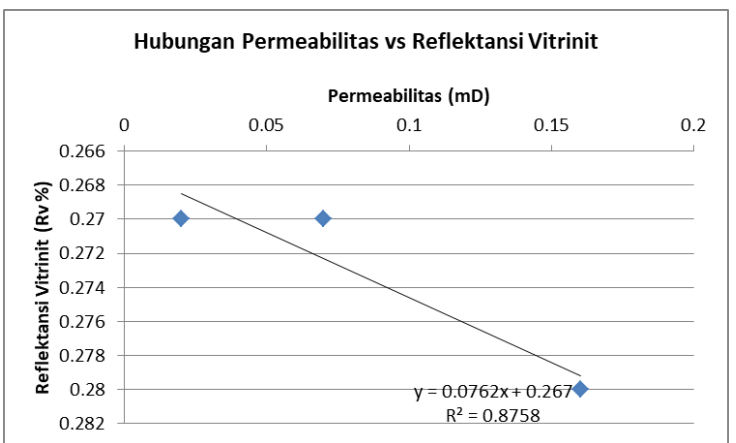

Gambar 7. Grafik permeabilitas terhadap reflektansi vitrinit

Keterkaitan antara pendekatan permeabilitas terhadap kandungan gas berbanding lurus, sehingga semakin besar nilai permeabilitas, maka semakin besar juga nilai kandungan gasnya (Gambar 8).

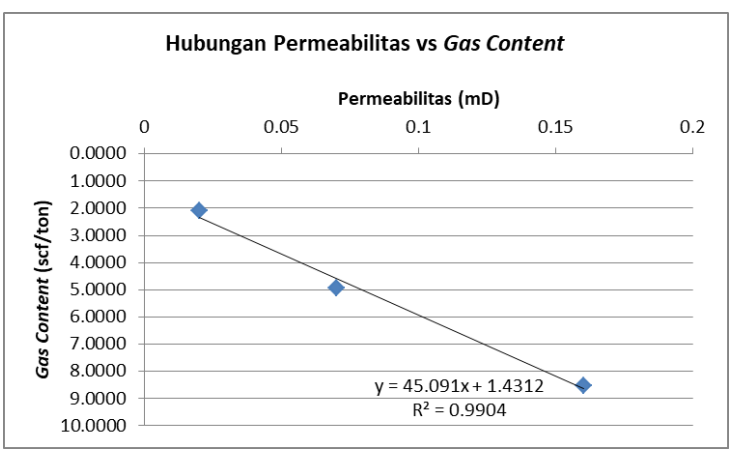

Gambar 8. Grafik permeabilitas terhadap gas content
Keterkaitan antara kedalaman lapisan batubara terhadap kandungan gas berbanding lurus, sehingga semakin dalam lapisan batubara maka semakin besar kandungan gas (Gambar 9).

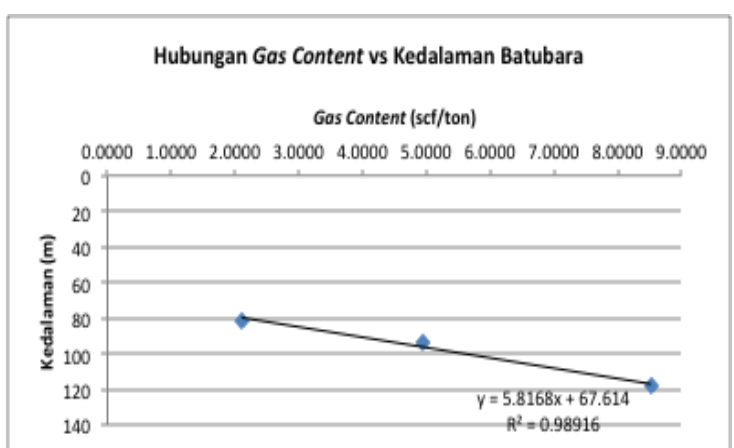

Gambar 9. Grafik kandungan gas terhadap kedalaman lapisan batubara

Grafik korelasi kedalaman terhadap kandungan gas mendapatkan persamaan $y=5,8168 x+67,614$, maka apabila dimasukkan nilai ambang batas kandungan gas minimal $10 \mathrm{scf} / \mathrm{ton}$ sesuai kriteria lapisan batubara yang berpotensi untuk GMB berdasarkan hasil diskusi dengan Divisi Perencanaan Eksplorasi (2016),, maka diperlukan kedalaman lapisan batubara minimal $125,78 \mathrm{~m}$. Apabila kedalaman lapisan batubara sesuai kriteria potensi gas metana batubara minimal berada pada kedalaman $300 \mathrm{~m}$, dihitung menggunakan persamaan, maka akan didapatkan kandungan gas sebesar 39,95 scf/ton.

Grafik korelasi permeabilitas terhadap kandungan gas mendapatkan persamaan y $=45,091 \mathrm{x}+1,4312$, maka apabila dimasukkan kandungan gas minimal 10 scf/ton, didapatkan permeabilitas $0,19 \mathrm{mD}$. Apabila dimasukkan kandungan gas 39,95 scf/ton, dengan harapan mempunyai kedalaman lapisan batubara 300 m, maka diperlukan permeabilitas sebesar 0,85 mD. Dengan demikian, apabila tidak melihat faktor lain, hanya berdasarkan perhitungan, dengan asumsi korelasi kedalaman terhadap kandungan gas, serta korelasi permeabilitas terhadap kandungan gas, maka anggota M3 Formasi 
Muaraenim pada daerah Mangunjaya akan mempunyai potensi gas metana batubara yang cukup menjanjikan sesuai kriteria potensi GMB, yaitu kedalaman minimal lapisan batubara $300 \mathrm{~m}$, kandungan gas 39,95 scf/ton, dan diperlukan permeabilitas lapisan batubara sebesar 0,85 mD.

Cekungan Sumatra Selatan saat ini masih merupakan cekungan yang memiliki potensi GMB cukup baik di Indonesia. Berdasarkan hasil rangkuman data oleh Divisi Perencanaan Eksplorasi (2019) dalam paparan mengenai GMB, sebagian besar badan usaha GMB di Cekungan Sumatra Selatan menyasar anggota M2 Formasi Muaraenim. Anggota M2 secara potensi memang lebih menjanjikan dibandingkan dengan anggota lainnya (Gambar 10), akan tetapi dalam penelitian ini memperlihatkan, apabila anggota M3 Formasi Muaraenim mempunyai kedalaman yang cukup untuk GMB, ketebalan batubara yang cukup tebal, serta kondisi reservoir GMB dengan permeabilitas yang bagus, maka bukan tidak mungkin anggota $\mathrm{M} 3$ akan menjadi target GMB di Cekungan Sumatra Selatan.

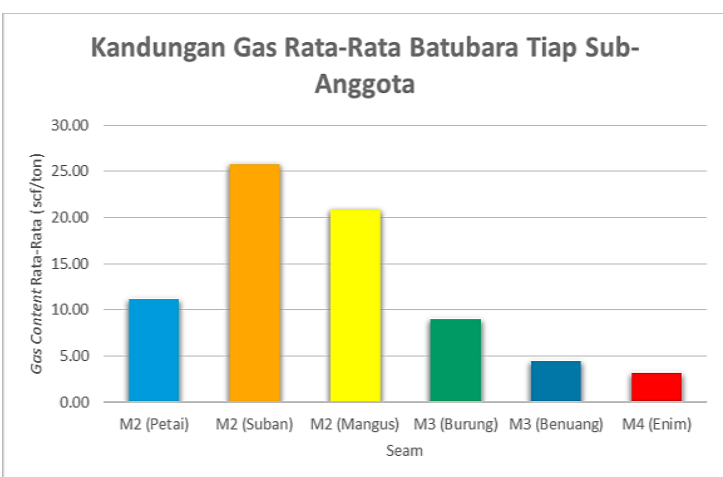

Gambar 10. Kandungan gas tiap anggota Formasi Muaraenim (Corinna, 2019)

Menurut Sosrowidjojo, 2013, potensi reservoir GMB di Formasi Muaraenim mempunyai nilai permeabilitas hingga 10 $\mathrm{mD}$, gas content lebih besar dari $15 \mathrm{scf} / \mathrm{ton}$, kandungan gas metena hingga $90 \%$, tebal lapisan batubara berkisar $10 \mathrm{~m}$, dengan kedalaman antara $400-800 \mathrm{~m}$. Berdasarkan data tersebut, maka potensi GMB di Formasi Muaraenim masih cukup baik, sehingga penelitian dan pembuktian masih sangat dibutuhkan.

\section{KESIMPULAN DAN SARAN}

\section{Kesimpulan}

Berdasarkan analisis microcleat, semakin dalam lapisan batubara, maka aperture face cleat semakin lebar. Terlihat dari pengamatan dibawah mikroskop, beberapa mineral seperti pirit, lempung, dan oksida besi mengisi cleat.

Lebar aperture face cleat memengaruhi nilai permeabilitas. Semakin besar nilai permeabilitas, maka semakin besar kandungan gasnya. Penelitian membuktikan bahwa semakin dalam lapisan batubara, maka semakin besar nilai permeabilitas, dan semakin besar kandungan gasnya. Cleat pada daerah penelitian diinterpretasikan di kontrol oleh aktivitas tektonik, aperture yang diamati merupakan aperture eksogenik yang tidak terpengaruhi oleh pembebanan atau proses pembatubaraan. Hal ini dilihat dari hubungan antara peringkat batubara dari nilai kalori batubara dan reflektansi vitinit yang saling tidak berhubungan, serta tidak terkait dengan spasi dan aperture cleat. Kedalaman sampel batubara yang masih dangkal juga memengaruhi proses terjadinya cleat pada daerah penelitian.

Anggota M3 Formasi Muaraenim mempunyai potensi GMB dengan target kedalaman $>300 \mathrm{~m}$ sehingga cukup untuk reservoir GMB, ketebalan batubara cukup tebal, serta kondisi permeabilitas baik. Penelitian ini memperlihatkan anggota M3 Formasi Muaraenim dapat mempunyai kandungan gas 39,95 scf/ton, pada permeabilitas lapisan batubara sebesar $0,85 \mathrm{mD}$, dengan kedalaman Iapisan batubara $300 \mathrm{~m}$.

\section{Saran}

Pengujian permeabilitas secara langsung perlu dilakukan pada lubang bor pada target lapisan batubara, sehingga dapat membandingkan asumsi-asumsi yang ada. Pembuktian kandungan gas dan 
permeabilitas pada anggota M3 dari Formasi Muaraenim perlu dilakukan untuk melihat potensi anggota M3 pada kedalaman minimal $300 \mathrm{~m}$.

\section{DAFTAR PUSTAKA}

Bishop, M.G., 2001, South Sumatra Basin Province, Indonesia: The Lahat/Talang Akar-Cenozoic Total Petroleum System, United State Geological Survey, Colorado.

Corinna, A., 2019, Skripsi : Pengaruh Karakteristik Batubara Terhadap Gas Content pada Formasi Muaraenim di Cekungan Sumatra Selatan, Universitas Padjajaran, Bandung.

Darman, H. dan Sidi, F.H., 2000, An Outline of The Geology of Indonesia, Ikatan Ahli Geologi Indonesia, Jakarta.

Divisi Perencanaan Eksplorasi, 2016, Materi presentasi: Tahapan dan Pencapaian Eksplorasi GMB Indonesia, SKK Migas, Jakarta.

Divisi Perencanaan Eksplorasi, 2019, Materi presentasi: Sumber Daya Migas Unkonvensional (GMB), SKK Migas, Jakarta.

Ibrahim, M.A., Rahmat, S.B., Ulfa, R.M., Priyono, Susana, N., 2017, Evaluasi Potensi CBM dan Batubara Bawah Permukaan Daerah Mangunjaya dan sekitarnya, Kabupaten Musi Banyuasin, Provinsi Sumatra Selatan, Pusat Sumber Daya Mineral Batubara dan Panas Bumi, Bandung. Laporan tidak dipublikasikan.
Ilyas, S., Ibrahim, D., Fatimah, 2000, Pengkajian Endapan Batubara Bersistem Dalam Cekungan Sumatra Selatan Di Daerah Sekayu Mangunjaya, Kabupaten Musi Banyuasin, Provinsi Sumatra Selatan, Direktorat Sumberdaya Mineral, Bandung. Laporan tidak dipublikasikan.

Linggadipura, R.D., Prasetyo, M.H., Dimas, E., 2016, Karakteristik Kuantitatif Cleat Sebagai Indikator Gas Metana Batubara di Kabupaten Bengkulu Utara, Provinsi Bengkulu, Proceedings Seminar Kebumian Ke9, hal. 199-210.

Patra Nusa Data, 2006, Indonesia Basin Summaries, PT Patra Nusa Data, Jakarta.

PSDMBP, 2020, Laporan Neraca Sumber Daya Batubara, Gambut, dan GMB, Pusat Sumber Daya Mineral Batubara dan Panas Bumi, Bandung.

Sosrowidjojo, I.B., 2013, Coal Geochemistry of The Unconventional Mearaenim Coalbed Reservoir, South Sumatra Basin: A Case Study From The Rambutan Field, Indonesian Mining Journal, Vol.16, No.2, p. 71-81.

Suarez-Ruiz, I. dan Crelling, J.C., 2008, Applied Coal Petrology, Elsevier, Burlington.

Yudha, S.S. dan Purnama, A.B., 2019. Identifikasi karakteristik kekar batubara Lapisan Batubara D berbasis pengamatan singkapan, korelasi data log sonic dan kualitas massa batuan (RQD). Jurnal Teknologi Mineral dan Batubara, vol. 15, no. 2, h. 77-88.

\begin{tabular}{|ll|}
\hline Diterima & $: 15$ Februari 2021 \\
Direvisi & $: 22$ Februari 2021 \\
Disetujui & $: 18$ Mei 2021 \\
\hline
\end{tabular}

